\title{
TEACHING ENGLISH TO CHINESE MASTER'S DEGREE STUDENTS AT A NON-LINGUISTIC UNIVERSITY IN RUSSIA
}

\author{
Evgeny Chigirin $^{1 \star}$, Vera Frolova ${ }^{2}$, Lidia Vitruk ${ }^{3}$, Tatiana Chigirina ${ }^{4}$ \\ ${ }^{1}$ Assoc. Prof. Dr., Voronezh State University of Engineering Technologies, \\ The Russian Federation, echgrn@gmail.com \\ ${ }^{2}$ Assoc. Prof. Dr., Voronezh State University of Engineering Technologies, \\ The Russian Federation, verairafrolova@mail.ru \\ ${ }^{3}$ Dr., Voronezh State University of Engineering Technologies, \\ The Russian Federation, balllet@yandex.ru \\ ${ }^{4}$ Assoc. Prof. Dr., Voronezh State University of Engineering Technologies, \\ The Russian Federation, chigirina-t@rambler.ru \\ ${ }^{*}$ Corresponding Author
}

\begin{abstract}
Nowadays the number of foreign students is being increased in Russia. In this regard, the problem of highquality training of foreigners is attracting more and more attention. The current study is relevant in the context of Chinese students training because the quantity of students from China receiving education at Russian universities takes the second place after students from the CIS member states. The article is devoted to the problem of teaching English to Chinese students at Russian non-linguistic universities. It is described some factors influencing the choice of teaching technologies aimed at developing and strengthening skills in different language activities. The study was conducted in three stages.

The first stage was devoted to the study of pedagogical and methodological literature on the problem of adaptation to the new educational environment and the formation of communication skills in the process of teaching English to master's degree students from the People's Republic of China studying at the Faculty of Economics and Management; the research methodology was determined.

The second stage was aimed at identifying and implementing teaching technologies in the educational process in order to develop and consolidate skills and abilities in all types of speech activity when teaching English as a foreign language in accordance with the academic course working program; the necessary pedagogical conditions were determined.
\end{abstract}

At the third stage, the results were summarized and analyzed, "Guidelines for practical classes" as well as "Guidelines for independent work of master's degree students" were published.

It should be noted here that teaching English to Chinese students in Russia is not an easy task. To develop an effective learning system, it is necessary to apply a wide range of didactic, general and special methodological principles. It is important to consider modern approaches to teaching foreign languages. Communicative orientation techniques and the principle of differentiated and integrated learning are supposed to be efficient among the general methodological principles that determine the formation of the language competence of Chinese students.

On the base of the analysis conducted, it was found out that Chinese students try to communicate only with friends from their home country which does not allow them to gain important educational and social experience from students of other nationalities. As a matter of fact, Chinese education is traditionally considered as a process of accumulating knowledge. They miss the opportunity to speak English outside the classroom.

Considering the peculiarities related to Chinese students it should be mentioned that the goals determined the choice of research methods. To reveal the state of the problem the analysis of pedagogical and 
psychological papers was used as a theoretical method. The authors also used some the empirical methods including observation, conversations, testing, and the method of mathematical statistics. All these research methods helped to develop appropriate technologies aimed at improving English language skills but also providing more effective adaptation of Chinese students to a new educational environment.

To assess the entry skills in English the Chinese students were given an entry test on five didactic units: 1) lexico-grammatical tasks (English in Use), 2) Listening, 3) Speaking, 4) Reading), 5) Writing. The criteria for completing the tasks of the written part were as follows: communicative problem solving, text organization, lexical presentation, grammar, orthography and punctuation. Speaking consisted of a monologue and a follow-up conversation with the lecturer on social and welfare topics and issues related to the previous educational stage. The volume of speech, the use of means of communication, the variety of lexical units and grammatical structures, the logic of the speech were assessed with the focus on solving a communicative problem.

On the basis of the results of the test, students could reach a maximum of $100 \%$. The general criteria for the evaluation of test tasks are as follows:

- $100 \%-85 \%$ of the correct answers - «Excellent»;

- $75 \%-84 \%$ of the correct answers- «Good»;

- $60 \%-74 \%$ of the correct answers- «Satisfactory»;

- under $60 \%$ of the correct answers- «Unsatisfactory».

Based on the results of the work during a year and entry and achievement tests, that demonstrated some progress in learning professional English by the students of the master's program in Economics, it is given grounds for the effectiveness of the use of interactive techniques. The authors consider problem-based and project-based learning methods, brainstorming technique, case-study, jigsaw reading to be of great importance as they help to create a favorable emotional environment in the classroom, to increase the activity of learners, and to develop communication skills of the Chinese culture representatives.

To sum up, it was revealed that a competent combination of traditional teaching methods with modern active methods allowed Chinese students to form new learning strategies, increase their motivation to learn a foreign language, as well as to solve some communicative, didactic and psychological problems associated with learning in a new educational environment. By performing the tasks based on the principles of active teaching methods, students gain new experience in solving communicative problems that are close to real life.

Keywords: International students, teaching methods, higher education, advanced teaching technologies.

\section{INTRODUCTION}

At present, the internationalization of higher education institutions is regarded as one of the priority aspects of the development of world higher education. Since the middle of the twentieth century, the number of foreign students in the world has grown more than 50 times and according to forecasts of international organizations (the UNESCO Institute for Statistics), their number is expected to increase up to 8 million people by 2025 (http: // uis.unesco.org/en /uis-student-flow). Russia is not an exception. In terms of quantity, Chinese students receiving education in Russian universities take the second place after students from the CIS member states. In this regard, high-quality training of foreigners at higher educational institutions is becoming one of the most pressing challenge.

In 2018, the Voronezh State University of Engineering Technologies joined the active process of attracting Chinese students, offering a master's program in "Economics "(profile "Industrial Business and the Economy of Innovation"). Among other disciplines the master's degree curriculum includes "English as a Foreign Language". The total student workload is determined as 5 credits or 180 academic hours, 112 hours being related to contact work (56 hours in each term).

The purpose of this research is to identify the key points of teaching English to master's degree students from China and to present an argument for the effectiveness of pedagogical technologies aimed at the student communication skills development.

When coming to study abroad, foreign students have to adapt not only to the educational process 
organization, but also to the foreign language teaching technologies, new requirements and a knowledge control system.

The adaptation process also contributes to the development of new skills for independent work as learners face communication difficulties in interpersonal communication; they have to cope with the information overload of the new socio-cultural and educational environment. As Timofeeva E. K. points out, the problem is aggravated by the fact that the Russian lecturers don't speak Chinese as well as students don't know Russian, so, they have to overcome some difficulties throughout the entire teaching process in choosing the methods aimed at optimizing students' English language proficiency and making educational process more effective (Timofeeva, 2008, pp. 229-232).

Thus, the relevance of the study is evident and it is influenced by a number of factors listed above.

\section{LITERATURE REVIEW}

To study the material on the research theme it was used some scientific articles, works of different scientists in the field of teaching methods, pedagogy, ethnopedagogy and ethnopsychology such as E. N. Solovova, I. A. Zimnaya, E. I. Pasov, N. Yu. Filimonova, A. B. Antonova, Rao Zh., Sit, H. H. W., Zhu J., Littlewood W., Woodrow L., Yang, Ch., etc.

Our analysis of materials on the problem of foreign language teaching methods in China allows us to identify some main features of the system of teaching a foreign language, namely, the traditional approach of the teacher to learning, that is, the knowledge of the language is evaluated precisely by the ability or inability to perform a particular exercise in such types of speech activity as listening, reading, and writing (Myasnikova, 2017, p.152). Chinese education is traditionally considered as a process of accumulating knowledge. Influenced by their previous educational practices, international students may be more accustomed to listening and learning rather than speaking in the classroom. As Sit noted, "the feature of "silent learning" can be traced back to the Confucian tradition which encourages the Chinese to respect hierarchical relationships in the society. Knowledgeable people like scholars and teachers are greatly respected as good role models. To keep order and harmony, students are usually permitted to speak up until being called upon. Listening attentively throughout the class is kept as a virtue for generations and generations". He also mentioned that "historically China's traditional education is examination-oriented. Learning for exams is still dependent on memorization" (Sit, 2013, p. 28).

On the base of the analysis conducted, we found out one more feature related to Chinese students: the fact that they try to communicate only with friends from their home country does not allow them to gain important educational and social experience from students of other nationalities. They miss the opportunity to speak English outside the classroom. We agree with Chunling Yang saying that "It is not surprising that international students feel more comfortable making friends and seeking help from students from their home country, but if the university can find ways for international students to communicate not only with their own cultural circle, but also with other international students and domestic students, a more useful and meaningful learning and living experiences will be offered to both international and domestic students" (Yang, 2017, p. 19).

All these factors lead scientists such as Hellmundt, S., Alison McCallum and others to the decision that it is necessary to "emphasize a student-centred learning environment where students are encouraged to speak up in class and participate in group assignment work". (McCallum, 2004, p.23). The effectiveness of learning a foreign language depends on teaching methods greatly. One of the teaching techniques which is "centered on students and chooses appropriate teaching content to develop students' communicative competence" is communicative teaching method. (Hellmundt, 2003, p.107). According to Binglan Yin, it "takes language teaching as an actual communication process. When organizing teaching activities, teachers need to know each student in advance, be familiar with their learning situation, consider the students' English proficiency and ability, and create a suitable language environment so that each student can participate". He is sure that only by dare to speak and speak more English can the English level and communicative competence improved. (Yin, 2019, p. 28).

Teaching English to Chinese students in Russia is not an easy task, so to develop an effective learning system, it is necessary to take into account and apply in teaching practice a wide range of didactic, general and private methodological principles, as well as the principles that underlie modern approaches to teaching foreign languages. Among the general methodological principles that determine the formation of the language competence of Chinese students, in our opinion, are the principle of communicative orientation and the principle of differentiated and integrated learning. 


\section{METHODOLOGY}

The tasks determined the choice of research methods. As a theoretical method we used the analysis of pedagogical and psychological literature that reveals the state of the problem under study. Among the empirical methods we should mention observation, conversation, testing, and the method of mathematical statistics. Different research methods application allowed us to develop appropriate technologies for teaching English to Chinese students and help them to adapt to a new educational environment.

\section{DISCUSSION AND FINDINGS}

The study was conducted in three stages.

The first stage was devoted to the analysis of pedagogical and methodological literature on the problem of adaptation to a new educational environment and the formation of communication skills in the process of teaching English to Master's degree students from China; the research methodology was determined.

The second stage was aimed at identifying and implementing teaching technologies in the educational process in order to develop and consolidate skills and abilities in all types of speech activity when teaching English as a foreign language in accordance with the academic course working program; the necessary pedagogical conditions were determined.

At the third stage, the results were summarized and analyzed, as well as "Guidelines for practical classes" and "Guidelines for Master's degree student independent work" were published.

The experimental group consisting of 49 master's degree students from China studying at the Faculty of Economics and Management were divided into 4 groups for learning English.

In order to determine the level of English knowledge the Chinese students were given an entry test on five didactic units: English in Use, Listening, Speaking, Reading and Writing. The criteria for completing the tasks of the written part were as follows: communicative problem solving, text structure, lexical presentation, grammar, orthography and punctuation. Speaking consisted of a monologue and a follow-up discussion with the lecturer on the problem of life activity and issues related to the previous educational experience. It was assessed the speech content, the speech patterns, the use of means of communication, the variety of lexical units and grammatical structures, the logic of the speech. The main criterion of the assessment was the fulfilment of the communicative task.

On the basis of the test results, students could reach a maximum of $100 \%$. The general criteria for the test tasks assessment are as follows:

- $100 \%-85 \%$ of the correct answers - «Excellent»;

- $75 \%-84 \%$ of the correct answers- «Good»;

- $60 \%-74 \%$ of the correct answers- «Satisfactory»;

- under $60 \%$ of the correct answers- «Unsatisfactory».

The results of the entry test are shown in Table 1.

Table 1. Diagnostic results of Chinese students' English proficiency (entry test assessment)

\begin{tabular}{|c|c|c|c|c|c|c|}
\hline Grade & $\begin{array}{c}\text { Group 1 } \\
\text { (12 students })\end{array}$ & $\begin{array}{c}\text { Group 2 } \\
(12 \text { students })\end{array}$ & $\begin{array}{c}\text { Group 3 } \\
(12 \text { students })\end{array}$ & $\begin{array}{c}\text { Group 4 } \\
(\mathbf{1 3} \text { students })\end{array}$ & $\begin{array}{c}\text { Total } \\
(49 \\
\text { students })\end{array}$ & $\begin{array}{c}\text { Total, } \\
\%\end{array}$ \\
\hline Excellent & 4 & 3 & 4 & 5 & 16 & $32,7 \%$ \\
\hline Good & 4 & 5 & 5 & 5 & 19 & $38,7 \%$ \\
\hline Satisfactory & 4 & 4 & 3 & 3 & 14 & $28,6 \%$ \\
\hline
\end{tabular}

This test allowed us to identify the strengths and weaknesses of the students knowledge and to plan the Educational Process Effectively Throughout The Academic Year.

On The Basis Of The Results Obtained, We Have Concluded That Most Of The Chinese Master's Degree 
Students Have A Good Vocabulary And Sufficient Grammar Skills To Perform Various Exercises, But Face Difficulties In Listening And Have A Certain Psychological Barrier In The Communication Process. Being Abroad Chinese Students Have Great Difficulties In Understanding And Using English (Yang, 2017, Pp. 420; Timofeeva, 2008, Pp. 15-17). H. Sit Attributes It To The Fact That A Well-Established Tradition In Chinese Educational Institutions Dictates The Method Of Silence, Passive Learning, Learning By Heart, I.E. Styles That Have A Negative Impact On The Adaptation Of Chinese Students And The Development Of Their Communicative Competence (Sit, 2013, Pp. 36 - 39). Taking Into consideration all these facts teachers face the problem of determining such technologies that combine traditional forms of teaching and new interactive methods which, in our opinion, "should gradually take a leading place in the general system of education as they demonstrate significant qualitative (such factors as better knowledge, more effective skills, important competencies, character development) and quantitative (improved learning parameters such as test results, volume of information learned, amount of skills or competencies developed) benefits" (Frolova, Chernykh, and Bykovskaya, 2018, pp. $36-39$ ).

We consider the following teaching methods applying to Chinese students to be the most effective:

- Problem-based learning aimed at use of knowledge not in one discipline, but in other related subjects as well. The process of solving the problems implies a combination of inductive and deductive methods of organizing thinking activity. As a result, students are able to think independently while being involved into the process of problem solving and decision making;

- A method of brainstorming which is aimed at solving the problems through collective discussion, generating ideas, followed by analysis and critical selection of proposals;

- Case study, which contributes to the formation of the student's ability to think globally, perceive and analyze information critically, highlight the main idea, find means and arguments to justify and confirm their own opinion;

\section{- A project-based learning promotes the development of students' creative potential.}

The use of interactive methods presupposes full integration of each student learning a foreign language into the process of mastering and applying educational material in practice. In its tern it develops teamwork skills and increases cognitive motivation. The use of above-mentioned methods activates students' thinking activity, encourages constant creative search, information analysis, and makes speech logically structured (Frolova, and Miroshnichenko, 2016, p. 75].

Given Chinese students' English proficiency and the postulate that learning in China is centered on a textbook being a guarantee of students' calm, because they can always refer to the material they have studied or find new information in the course of completing tasks, we have chosen course "Market Leader Intermediate. Business English" by Cotton D., Falvey D., Kent S. being one of the most popular Business English Courses (Cotton, Falvey, and Kent, 2016). It comprises up-to-date information concerning economics and business and a lot of activities aimed at consistent tasks implementation. The great advantage of this course, which includes a textbook, a workbook, a set of tests, a DVD-ROM and a teacher's book, is a wide range of topics. The course reflects the fast-changing word of business using authoritative and authentic business sources as the Financial Times. Each module gives the opportunity to combine traditional methods and interactive technologies, including business games, group discussions, and case studies, which are aimed at the formation of:

- Creative approach to communication;

- Speaking, listening, and business writing skills;

- Ability to work in a team and interact with each other effectively.

All kinds of activities presented in the Course Book increase students' interest and engage them in the learning process as much as possible. When solving the problems given in Case Study section students develop the ability to listen to each other, to take into account an alternative point of view and to express their own opinion. As foreigners they learn how to adapt to new language environment, facing everyday situations. Therefore, while doing the course the number of active participants in communication was increasing acquiring the skills of independent productive speaking. It should be noted that the majority of Chinese students are highly motivated to learn English. In addition, they are hardworking, executive, disciplined, independent, self-possessed and a little reserved. At the same time, they have already developed a certain model of behavior which is to express their own opinion only when they are asked by a teacher. So, they in fact have no desire for self-expression through speaking. The fear of making a mistake 
and "losing face" in front of others is a characteristic feature of the Chinese mentality. That is why it is very important to take into account the individual and ethno-cultural characteristics of this category of students, creating a favorable atmosphere that allows them to overcome the fear of communicating in English and more actively engage them in such activities that help to develop communication skills. As Antonova A. B. puts it, during the planning, selection and presentation of educational materials, it is necessary to proceed from the national psychotype and cognitive style of learning activity of Chinese students (deductive methods of mastering the material, relying on the visual image, the use of imitations and analogies, followed by the transition to transformations and construction) (Antonova, 2017, p. 75). The main organizational forms of teaching English to Chinese students were classroom individual work, collective-group work and work in mini-groups, extracurricular individual work of students, independent work of students, searching for material to prepare reports, presentations, and writing business letters. It should be noted that the supervised independent work under the guidance of a teacher included the reading of authentic scientific literature dealing with master's degree direction. A graduate of a non-linguistic university is supposed to receive the skills to obtain professionally oriented information from foreign-language sources quickly. The practice of teaching a foreign language for specific purposes shows that students experience significant difficulties when reading authentic texts. Students do not know the techniques and methods of obtaining professionally relevant information from texts. Therefore, the question arises about such means of teaching reading that provide an enrichment of students 'vocabulary, the development of skills for analyzing original scientific and technical literature, and also contribute to improving the communication abilities of students.

Based on the application of the jigsaw reading technology, we have developed a set of exercises for each stage of working with an authentic scientific and technical text, including the pre-text (pre-reading), text (reading) and post-text (after reading) stage.

The pre-text stage (pre-reading) prepares students to read the text, serves to encourage their interest in reading, and eliminates the barrier of language difficulties. Students get acquainted with the new words and expressions; determine the problems of the text. At this stage, it is advisable to use such exercises as:

- Try to understand the meaning of the words given bellow;

- Guess what these terms mean, choose one of the possible meaning given, then check with the dictionary;

- What facts do you know about?

The text stage (reading) tests the students' communicative skills and their further improvement takes place. At this stage of the work, tasks are performed for a detailed analysis of the text, understanding its content:

- Find synonyms or antonyms to the words given bellow;

- Match the words from two columns to make word combinations;

- Fill in the gaps in the sentences with appropriate words or combinations;

- Find key words or combinations in each abstract etc.

At this stage a very interesting technique "Insert" is used. The technique is the following: while reading the text students make some notes in the copybook, and after that they fill in a marking table, the headings of which are the following symbols: "V" stands for "I knew the information"; " + " stands for "the information is new to me"; " - " stands for "I thought otherwise"; "? " stands for "I did not understand, there are questions".

The post-text stage (after reading) is a means of developing productive skills such as speaking or writing, based on the authentic material read. A number of strategies are effectively applied at the final stage. The "REST" technique is one of them (Record/ Edit/ Synthesize/ Think), which involves fixing the key aspects of each text fragment, and at the end of studying the material students review the accumulated information, edit it and synthesize it into a single meaningful text. There are also good reasons to use the "Cinquain" method, which "helps to solve such educational tasks as summarizing the activities applied working with the text; fixing new vocabulary, and others. It is a synthesis of information in a concise form, which allows to describe the essence of the concept based on the knowledge gained, namely, it makes it possible to summarize information, present complex ideas and representations in a few words". Thus, the final stage is aimed at developing speaking skills, i.e. after working with the text; the teacher should motivate students to create secondary texts: dialogues, retelling, discussions, mini-conferences, etc. This integration of different aspects of speech allows to obtain the necessary material from the text itself and provides a solution to the main task that is communication of students in order to exchange professional information.

The use of these methods contributes not only to the creation of a favorable emotional environment and 
much more efficient work of Chinese students, even those who have low abilities to learn a foreign language, but also to the development of necessary knowledge and skills. Students try to accept and maintain the communicative intention, plan its implementation, adjust and control their actions, as well as the skills and abilities of verbal and non-verbal interaction. The results of the final assessment are shown in Table 2.

Table 2. Diagnostic results of Chinese students' English proficiency (achievement test assessment)

\begin{tabular}{|c|c|c|c|c|c|c|}
\hline Grade & $\begin{array}{c}\text { Group 1 } \\
\text { (12students) }\end{array}$ & $\begin{array}{c}\text { Group 2 } \\
\text { (12students) }\end{array}$ & $\begin{array}{c}\text { Group 3 } \\
\text { (12students) }\end{array}$ & $\begin{array}{c}\text { Group 4 } \\
\text { (13students) }\end{array}$ & $\begin{array}{c}\text { Total } \\
\text { (49students) }\end{array}$ & $\begin{array}{c}\text { Total, } \\
\%\end{array}$ \\
\hline Excellent & 6 & 7 & 7 & 7 & 27 & 55,1 \\
\hline Good & 5 & 4 & 4 & 4 & 17 & 34,7 \\
\hline Satisfactory & 1 & 1 & 1 & 2 & 5 & 10,2 \\
\hline
\end{tabular}

The results of the final assessment have shown that the use of interactive teaching methods in practical English courses not only contributes to the acquisition of material, but also has a positive impact on the development of communicative skills. Learners gain experience in communication and group interaction.

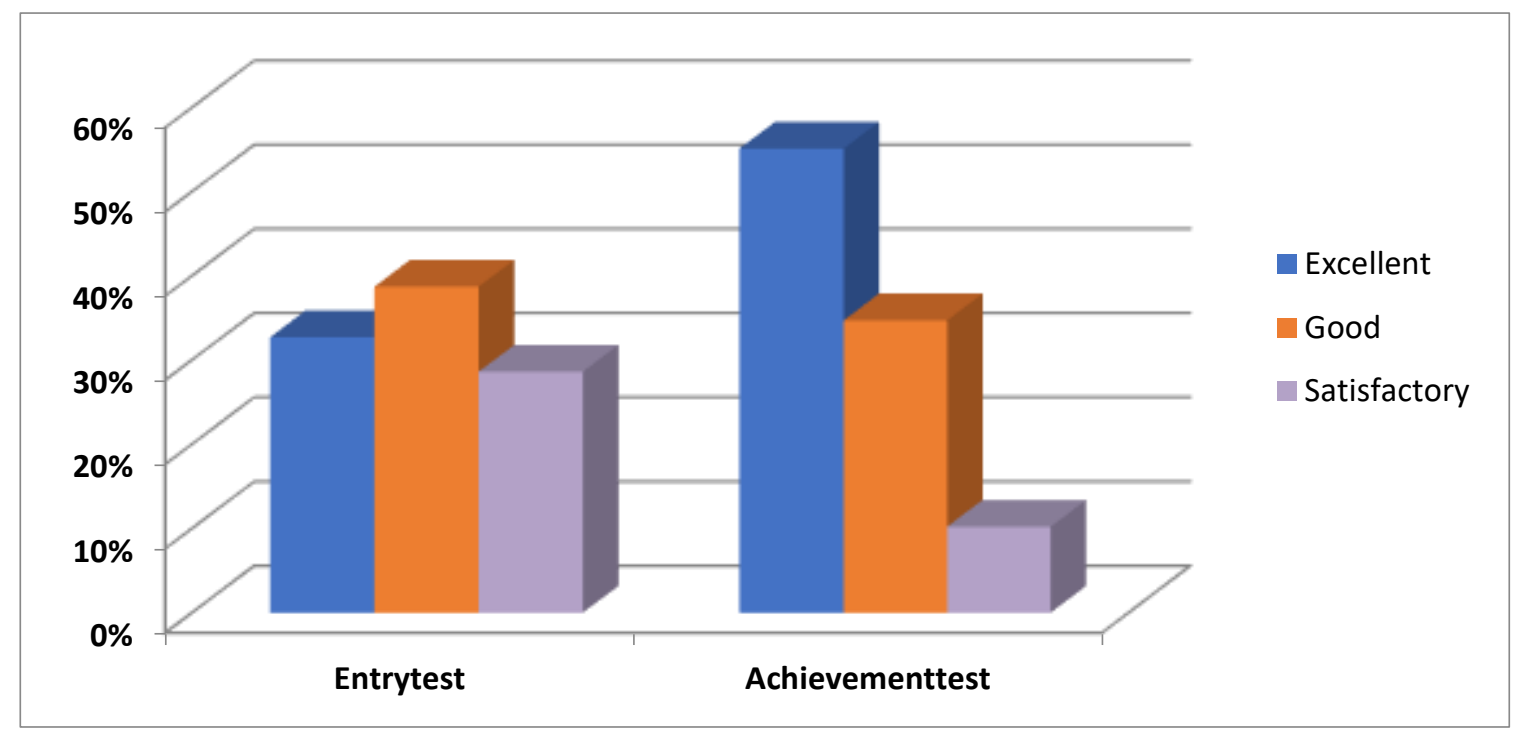

Fig.1. The comparative data of the results of both tests are presented in the figure 1 .

\section{CONCLUSION}

Specific mentality, socio-cultural and ethno-psychological features of Chinese students made the lecturers determine appropriate teaching technologies.

As a result of the research, it was found that a competent combination of traditional teaching methods with modern interactive techniques help Chinese students to form new learning strategies, to increase their motivation in foreign language learning, as well as to solve some communicative, didactic and psychological problems associated with learning in a new educational environment. By performing tasks based on the principles of active learning methods, students gain new experience in communicative tasks fulfilment under conditions close to the real life. They develop skills of the communicative role flexible change according to the different communicative situation.

\section{REFERENCE LIST}

Antonova, A. B. (2007). Modern trends in teaching Chinese schoolchildren and students English as a foreign language in educational institutions of Russia and China. Russian-Chinese studies, Vol.1, № 1. 
Cotton, D., Falvey, D., Kent, S. (2016). Market Leader Intermediate Business English Course Book. Pearson Education Limited.

Frolova, V.P., Chernykh, V.D., Bykovskaya, G.A. (2018). Innovative Technologies in Teaching Humanities at Technical Universities. The European Proceedings of Social \& Behavioural Sciences. Edited by: Prof. Valeria Chernyavskaya and Prof. Holger Kuße. 2018.

Frolova, V. P. Miroshnichenko, E. N. (2016). The Role of Interactive Learning in the Formation of Foreign Language Communicative Competence. Actual Problems and Modern Technologies of Teaching Foreign Languages in Non-Specialized Universities: Materials of the 9th All-Russian Scientific and Practical Conference of Non-Linguistic Universities with International Participation on the Basis of VGIFK.

Hellmundt, S. (2003). Linking intercultural teaching and learning practice: Promoting student voice through multicultural group work. [Online]: Available: http://www.Diversity Conference.com

McCallum, Alison (2004). MEd, BA, DipTchg, Dip Ed, (Guidance Studies). Best Practice Teaching Strategies for International Students, July. [Online]: Available: http://www.nzdl.org/gsdl/collect/literatu/index/assoc/HASH4388.dir/doc.pdf

Myasnikova, S. V. (2017). The Peculiarities of Teaching Chinese Students English in High School. Azimuth of Scientific Research: pedagogy and psychology. № 3(20).

Sit, H. H.W. (2013). Characteristics of Chinese students' learning styles. International proceedings of economics development and research. № 62.

Timofeeva, E. K. (2008). Three-Sided Interference: Linguistic, Culturological and Phonetic Aspects of Teaching English to Chinese Learners. Vestnik of Saint Petersburg University. №1.

Yang, Ch. (2017). Problems Chinese international students face during academic adaptation in Englishspeaking higher institutions. [Online]: Available: http://dspace.library.uvic.ca/bitstream/handle/1828/8086/Yang_Chunling_MEd_2017.pdf

Yin, Binglan (2019) Discussion on the Effective English Teaching Methods in Universities and Colleges. Review of Educational Theory, Vol. 2, Issue 01. [Online]: Available:

http://ojs.bilpublishing.com/index.php/ret 